\title{
PENERAPAN METODE BERMAIN PERAN (ROLE PLAYING) UNTUK MENGEMBANGKAN KECERDASAN INTRAPERSONAL DAN INTERPERSONAL ANAK
}

\author{
Rima Gontina ${ }^{1}$,Kanada Komariyah, Uswatun Hasanah ${ }^{3}$ \\ ${ }^{1}$ Universitas Islam Negeri Raden Intan Lampung, Bandar Lampung, Indonesia \\ Rimagontina@gmail.com
}

This study aims to determine the application of the role playing method (Role Playing) to develop children's interpersonal and intrapersonal intelligence. Every Child Has Their Intelligence. Children's interpersonal and intrapersonal intelligence is a very important intelligence to be developed from an early age. The formulation of the problem in this study is how the application of role playing methods to develop children's interpersonal and intrapersonal intelligence. The type of research used in this study is descriptive qualitative. Data collection techniques used are observation, interviews, and documentation. Data analysis techniques used are data reduction, data presentation, and drawing conclusions. Test the validity of the data using triangulation. Based on the results of research conducted by researchers that the implementation of the method of play has been implemented in accordance with the steps in playing the role. From the results of interpersonal intelligence in children in the underdeveloped category there are $0 \%$, starting to develop there are $18 \%$, children who develop according to expectations there are $59 \%$, and children who develop very well there are $23 \%$. Then for intrapersonic intelligence there are $0 \%$ of children who have not developed, $23 \%$ of children who start developing, $50 \%$ of children who develop according to expectations and $27 \%$ of children who develop very well.

\section{Keywords:Metode Bermain peran, Kecerdasan Interpersonal,Kecerdasan Intrapersonal}

\begin{abstract}
Abstrak
Penelitian ini bertujuan untuk mengetahui penerapan metode bermain peran (Role Playing) untuk mengembangkan kecerdasan interpersonal dan intrapersonal anak. Setiap Anak Memiliki Kecerdasannya masing-masing. Kecerdasan interpersonal dan intrapersonal anak merupakan kecerdasan yang sangat penting untuk dikembangkan sejak dini, Rumusan masalah pada penelitian ini adalah bagaimanakah penerapan metode bermain peran (role playing) untuk mengembangkan kecerdasan interpersonal dan intrapersonal anak, Jenis penelitian yang digunakan dalam penelitian ini adalah deskriptif kualitatif. Teknik pengumpulan data yang digunakan adalah dengan observasi, wawancara, dan dokumentasi. Teknik analisis data yang digunakan yaitu reduksi data, penyajian data, dan penarikan kesimpulan. Uji keabsahan data menggunakan triangulasi. Berdasarkan hasil penelitian yang peneliti lakukan bahwa penerapan metode bermain telah dilaksanakan sesuai dengan langkah-langkah dalam bermain peran. Dari hasil penelitian kecerdasan interpersonal anak dalam kategori belum berkembang ada $0 \%$, mulai berkembang ada $18 \%$, anak yang berkembang sesuai harapan ada 59\%, dan anak yang berkembang sangat baik ada 23\%. Kemudian untuk kecerdasan intrapersonalnya ada $0 \%$ anak belum berkembang, 23\% anak yang mulai berkembang, 50\% anak yang berkembang sesuai harapan dan $27 \%$ anak yang berkembang sangat baik.
\end{abstract}

Kata Kunci :Metode Bermain peran, Kecerdasan Interpersonal,Kecerdasan
Intrapersonal




\section{PENDAHULUAN}

Pendidikan adalah usaha sadar dan terencana untuk mewujudkan suasana belajar dan proses pembelajaran agar peserta didik secara aktif mengembangkan potensi dirinya untuk memiliki kekutan spiritual keagamaan pengendalian diiri kepribadian, kecerdasan, akhlak mulia, serta keterampilan yang diperlukan dirinya, masyarakat bangsa dan negara. $^{1}$

Usia dini memegang peranan yang sangat penting karena otak manusia mengalami lompatan dan berkembang sangat pesat pada usia tersebut, yakni mencapai $80 \%{ }^{2}$ Ini berarti pada masa ini adalah masa dimana anak mudah sekali menyerap apa yang diberikan lingkungannya. Masa perkembangan otak yang sangat dahsyat, dan perlu mendapatkan layanan yang optimal melalui pembenahan manajemen pendidikan dan lingkungan yang kondusif. Oleh karena itu hendaknya dimanfaatkan sebaik-baiknya untuk pemberian stimulus karena rasa ingin tahu anak usia dini sangatlah tinggi.

Pendidikan anak usia dini adalah usaha pembinaan yang ditujukan kepada anak sejak sampai usia enam tahun dengan cara pemberian rangsangan untuk membantu mengembangkan jasmani dan rohani anak sehingga mampu siap memasuki jenjang lebih lanjut. ${ }^{3}$

Pada rentang usia anak mengalama masa keemasan (golden age) yang merupakan masa dimana anak mulai peka atau sensitif untuk menerima rangsangan. Masa peka adalah masa adalah masa terjadinya kematangan fungsi fisik dan psikis, anak telah siap menerima respon dari lingkungan. ${ }^{4}$ Sehingga mereka tumbuh dengan perkembangan kecerdasan yang baik dan dapat berhubungan atau berinteraksi serta tolong menolong atau bekerjasama dengan sesamanya, sebagaimana firman Allah tentang tolong menolong sesama manusia dalam QS Al-Maidah [5]:2 sebagai berikut:

$$
\text { r }
$$

Artinya: “...Dan tolong-menolonglah kamu dalam (mengerjakan) kebajikan dan takwa, dan jangan tolong-menolong dalam berbuat dosa dan pelanggaran. Dan

1 Undang-Undang, Sistem Pendidikan Nasional (Yogyakarta: Pustaka Belajar, 2016).h.3

2 Mulyasa,Manajemen PAUD, (Bandung: PT Rosdakarya, 2016), h. 2.

3 Undang-Undang.OpCit, h.5

4 Panji Hermoyo, 'Membentuk Komunikasi Yang Efektif Pada Masa Perkembangan', Membentuk Komunikasi Efektif, 2014. 
bertakwalah kamu kepada Allah, sesungguhnya Allah amat berat siksa-Nya." (QS. A1Maidah [5]:2) ${ }^{5}$

Dengan demikian pendidikan agar kita beriman dan bertakwa kepada Allah. Pendidikan sudah dimulai sejak dini bahkan sejak dalam kandungan. Menurut J. Looke anak usia dini bagaikan tabula rasa, sebuah meja lilin yang dapat ditulis dengan apa saja bagaimana keinginan sang pendidik. ${ }^{6}$ Dalam hal ini berarti lingkungan disekitar anak khususnya pengasuh atau pendidik berperan sangat penting dalam merangsang perkembangan anak baik kognitif, kecerdasan maupun perkembangan fisiknya. Untuk merangsang perkembangan tersebut diperlukan sebuah usaha, sebagaimana firman Allah dalam QS.Ar-Rad [13]:11sebagai berikut:

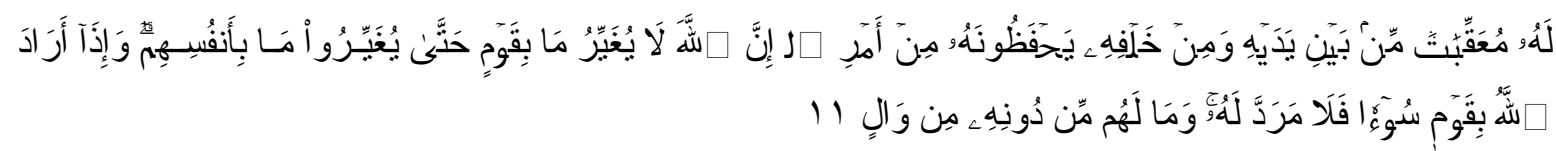

Artinya: "Baginya (manusia) ada malaikat-malaikat yang selalu mengikutinya bergiliran, dari depan dan di belakangnya, mereka menjaganya atas perintah Allah. Sesungguhnya Allah tidak merubah keadaan sesuatu kaum sehingga mereka merubah keadaan diri mereka sendiri. Dan apabila Allah menghendaki keburukan terhadap sesuatu kaum, maka tak ada yang dapat menolaknya; dan sekali-kali tak ada pelindung bagi mereka selain Dia” (QS. Ar-Rad [13]:11) ${ }^{7}$

Dari ayat di atas bahwasanya diperlukan adanya usaha untuk merubah suatu keadaan, agar perkembangan baik intektual, spiritual mapun kecerdasanya berkembang secara optimal. Dalam pendidikan untuk merangsang perkembangan anak usia dini tersebut dapat dilakukan dengan menggunakan berbagai strategi dan metode. Metode pembelajaran adalah cara untuk mempermudah peserta didik mencapai kompetensi tertentu

Dunia anak adalah bermain (Playing is the world of children). Bermain merupakan aktivitas utama yang dilakukan dalam kehidupan anak. Kegiatan bermain memberi manfaat positif untuk pengembangan potensi anak. Misalnya kecerdasan, bakat, kreativitas, keterampilan motorik, keterampilan sosial (social skill), keterampilan komunikasi (communication skill). ${ }^{8}$ Artinya dengan bermain anak dapat mengembangkan berbagai perkembangannya dengan cara yang sangat menyenangkan, anak dengan senang menerima

5 Al-Quran dan Tarjamah, Surat Al-Maidah ayat 2, (Bandung:PT Cordaba Internasional Indonesia, 2012), h.106

6 Suyadi, Teori Pembelajaran Anak Usia Dini (Bandung: PT Rosdakarya, 2014).

7 Al-Quran dan Tarjamah, Surat Ar-Rad ayat 11,(Bandung:PT Cordaba Internasional Indonesia, 2012), h. 250

8 T Musfiroh, 'Pengembangan Kecerdasan Majemuk', Hakikat Kecerdasan Majemuk (Multiple Intelegences), 60 (2014), 1-60 <http://repository.ut.ac.id/4713/2/PAUD4404-TM.pdf $>$. 
dan mempelajari apa yang ada dilingkungannya. Dengan bermain anak dapat bersosialisasi dengan lingkunganya.

Salah satu kegiatan bermain yang dapat menstimulasi kecerdasan anak ialah kegiatan bermain peran. Menurut Deni Damayanti berbagai kecerdasan dapat dikembangkan atau distimulus melalui kegiatan bermain. Bermain untuk mengembangkan kecerdasan interpersonal anak salah satunya bermain peran dan intrapersonal adalah olah tubuh. ${ }^{9}$ Pendapat ahli ini menyatakan bahwa salah satu cara mengembangkan kecerdasan anak adalah dengan bermain.

Metode role playing atau bermain peran adalah suatu cara penguasaan bahan-bahan pembelajaran melalui pengembangan imajinasi dan penghayatan siswa. Pengembangan imajinasi dan penghayatan dilakuan dengan memerankan tokoh hidup atau benda mati. ${ }^{10}$

Bermain peran adalah mengeksplorasi hubungan antar manusia dengan cara memperagakannya dan mendiskusikannya sehingga secara bersama-sama dapat mengeksplorasi perasaan, sikap, nilai, dan berbagai strategi pemecahan masalah. ${ }^{11}$ Melalui bermain peran anak-anak dapat berinteraksi dengan orang lain, melalui pemeranan mereka juga dapat melatih sikap empati,simpati, rasa benci senang, dan peran-peran lainnya. ${ }^{12}$ Dengan demikian dapat disimpulkan bahwasannya metode bermain peran adalah cara dalam menyampaikan pembelajaran atau merangsang perkembangan anak denga cara memerankan tokoh atau benda (dramatisasi) untuk mengeksplorasi hubungan antar manusia yang melibatkan anak/peserta didik langsung dalam kegiatannya.

Menurut Erik Erikson dalam buku Mukhtar Latif ada dua jenis main peran yaitu main peran kecil (mikro) dan bermain peran besar (makro). Main peran kecil (mikro) mengalirkan materi atau knowledge pada anak melalui alat main yang berukuran kecil anak sebagai dalang yang menggerakan boneka yang menjadi pemeran. ${ }^{13}$ Sentra main peran besar adalah sentra yang memberikan kesempatan kepada anak untuk mengembangkn pengertian mereka tentag dunia di sekitarnya, kemampuan berbahasa, keterampilan mengambil sudut pandang dan empati melalui peran yang mengalirkan knowledge pada anak. $^{14}$

Setiap orang memiliki semua tipe kecerdasan tetapi dalam tingkatan yang bervariasi. Akibatnya kita cenderung mempelajari dan memproses informasi dengan cara yang

9 Deni Damayanti, Senang Dan Bahagia Menjadi Guru PAUD (Yogyakarta: Araska, 2018). h.71-72

10 Jumanta Handayana, Model Dan Metode Pembelajaran Kreatif Dan Berkarakter (Bogor: Ghalia Indonesia, 2017). Sumber'.

11 Desti Pujiati, 'PAUD PPs Universitas Negeri Jakarta Pendidikan Anak Usia Dini Pengembangan

12 Mulyasa., Op-Cit 174

13 Mukhtar Latif, Pendidikan Anak Usia Dini (Jakarta: Prenadamedia Group, 2013).h.131

14Ibid, 130 
berbeda-beda. ${ }^{15}$ Kecerdasan dalam pengertian populer didefinisikan sebagai kemampuan mental umum untuk belajar dan menerapkan pengetahuan dan memanipulasi lingkungan, serta kemampuan untuk berpikir abstrak. ${ }^{16}$ Jadi kecerdasan merupakan kemampuan anak untuk menerapkan pengetahuan yang telah diterimanya.

Kecerdasan intrapersonal adalah kemampuan seseorang untuk mengolah diri, emosi dan pikiran. ${ }^{17}$ Karakteristik anak yang memiliki kecerdasan intrapersonal adalah menunjukan kemandirian dan keinginan yang kuat, mengerjakan sesuatu dengan baik ketika ditinggalkan sendiri, pandai mengatur diri sendiri, mau menunggu giliran, mampu mengambil pelajaran dari keberhasilan dan kegagalan dalam hidup. ${ }^{18}$

Dalam kaitannya dengan penelitian yang ingin penulis lakukan bahwa indikator yang ingin penulis teliti adalah tentang kemampuan memahami diri, seperti sabar menunggu giliran, percaya diri, semangat dalam bermain, mampu mengendalikan emosi dan kemampuan mengerjakan suatu dengan mandiri. Indikator yang ingin teliti adalah gabungan dari pendapat beberapa ahli yakni Yaumi,Raudhatul Janah dan Habibu yang disesuaikan dengan sistem pendidikan nasional no 137 tahun 2014

Kecerdasan interpersonal adalah kemampuan untuk berhubungan dengan orang-orang disekitar kita. Kecerdasan ini memungkinkan anak untuk membangun kedekatan dengan orang lain. Pengembangan kecerdasan interpersonal sejak dini menjadi sangat penting agar anak memilki kemampuan dalam membina hubungan dengan orang lain yang ada disekitarnya. Sebagaimana yang telah dijelaskan dalam alquran surat An-Nisa:4 sebagai berikut:

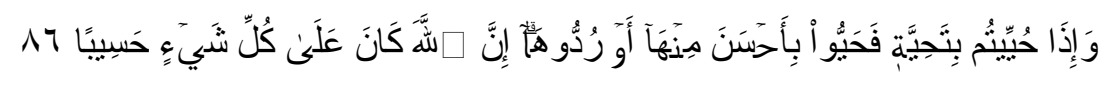

Artinya: “Apabila kamu diberi penghormatan dengan sesuatu penghormatan, maka balaslah penghormatan itu dengan yang lebih baik dari padanya, atau balaslah penghormatan itu (dengan yang serupa). Sesungguhnya Allah memperhitungankan segala sesuatu." (QS. An-Nisa [4]:86) ${ }^{19}$

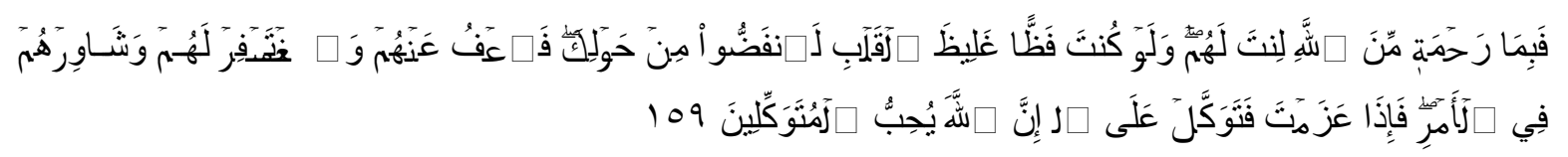

15 Kadek Suarca, Soetjiningsih Soetjiningsih, and IGA. Endah Ardjana, 'Kecerdasan Majemuk Pada Anak', Sari Pediatri, $2016<$ https://doi.org/10.14238/sp7.2.2005.85-92>.

16 Muhammad Yaumi dan Nurdin Ibrahim, Pembelajaran Berbasis Kecerdasan Jamak(Multiple Intelegensi), (Jakarta: Prenadamedia Group, 2016).h.9

17 Damayanti., Opcit. h.171

18Muhamad Yaumi dan Nurdin Ibrahim, Pembelajaran Berbasis Kecerdasan Jamak(Multiple Intelegensi), (Jakarta:Prenadamedia group,2016), h.18-27

19 Al-Quran dan Tarjamah, Surat An-Nisa ayat 86,(Bandung:PT Cordaba Internasional Indonesia, 2012), h.91 
Artinya :"Maka disebabkan rahmat Allah (Muhammad) berlaku lemah lembut terhadap mereka. Sekiranya kamu bersikap keras lagi berhati kasar, tentulah mereka menjauhkan diri dari sekitarmu. Karena itu maafkanlah mereka, mohonkanlah ampun bagi mereka, dan bermusyawaratlah dengan mereka dalam urusan itu. Kemudian apabila kamu telah membulatkan tekad, maka bertawakkallah kepada Allah. Sungguh Allah mencintai orang-orang yang bertawakal.” (QS Al 'Imran [3].159) ${ }^{20}$

Dari kedua ayat diatas bahawasnya sebagai manusia kita harus saling menghargai dan berprilaku baik dengan sesama manusia, berlaku lemah lembut dan saling menghormati.

Dalam kaitannya dengan penelitian ingin penulis lakukan bahwa indikator yang ingin penulis teliti adalah tentang kecerdasan interpersonal anak adalah kemampuan bekerjasama, kemampuan berempati dan peduli, mau berbagi, senang berinteraksi dan menghargai orang lain. Indikator diambil dari pendapat Raudhatul janah, Habibu Rahman dan Yaumi yang dipadukan dengan sistem pendidikan nasional No 137 tahun 2014.

Kecerdasan intrapersonal dan intrapersonal anak sangat penting untuk dikembangkan sejak dini, dimana dari pembahasan yang telah diuraikan di atas bahwasannya kecerdasan intrapersonal adalah kemampuan anak dalam mengendalikan diri dan emosi dan kecerdasan intrapersonal adalah kemampuan dalam berhubungan dengan orang lain. Dengan demikian mereka diharapkan dapat mengendalikan diri dan dapat berhubungan dengan orang lain.

Berdasarkan penelitian sebelumnya oleh Muhammad Yusri Bahtiar pada tahun 2017dalam jurnal awlady: Jurnal Pendidikan Anak didapatkan hasil bahwa metode Bermain Peran berpengaruh terhadap kecerdasan interpersonal Pada Anak Kelas A di Tk Buah Hati Kota Makassar. ${ }^{21}$ Dalam Jurnal Pendidikan Anak Usia Dini Tahun 2013 oleh Andrius Krobo Kecerdasan Intrapersonal dapat ditingkatkan dengan menerapkan metode bermain peran. ${ }^{22}$

Persamaan penelitian ini dengan penelitian terdahulu adalah sama-sama membahas tentang metode bermain peran (role playing), kecerdasan interpersonal dan intrapersonal. Perbedaannya peneliti meneliti keduanya baik kecerdasan interpersonal maupun kecerdasan intrapersonalnya dalam penelitian ini penulis menggunakan jenis penelitian deskriptif kualitatif yang tujuannya untuk mengetahui penerapan metode bermain peran untuk mengembangkan kecerdasan interpersonal dan intrapersonal anak di TK Pratama Kids Sukabumi Bandar Lampung

20 Al-Quran dan Tarjamah, Surat An-Nisa ayat 86,(Bandung:PT Cordaba Internasional Indonesia, 2012), h.71

21 Muhammad Yusri Bachtiar, 'Interpersonal Pada Anak Kelas A Di Tk Buah Hati Kota Makassar', Jurnal Pendidikan Anak, 3.2 (2017).

22 ANDRIANUS KROBO, 'Peningkatan Kecerdasan Intrapersonalmelalui Kegiatan Bermain Peran', Pendidikan Usia Dini, 8.1 (2014), 25-34 <https://www.neliti.com/publications/117495/peningkatankecerdasan-intrapersonalmelalui-kegiatan-bermain-peran $>$. 


\section{METODE PENELITIAN}

Penelitian ini menggunakan metode deskriptif kualitatif yang mana fokus penelitian ini bertujuan untuk mengetahui penerapan metode bermain peran (role playing) untuk mengembangkan kecerdasan interpersonal anak dan interpersonal anak .

Subjek dari penelitian ini adalah 22 anak. Teknik pengumpulan data menggunakan observasi (pengamatan), wawancara, dan dokumentasi. Teknik analisis data adalah reduksi data, display data dan penarikan kesimpulan. Uji keabsahan data menggunakan triangualasi.

\section{HASIL PENELITIAN DAN PEMBAHASAN}

Berdasarkan hasil observasi, wawancara, dan dokumen penulis menyimpulkan bahwasannya penerapan metode bermain peran untuk mengembangkan kecerdasan interpersonal dan intrapersonal anak yang dilaksanakan di TK Pratama Kids Sukabumi Bandar Lampung sudah diterapkan sesuai dengan langkah-langkah yakni:

1. Guru Menetepkan dan Memilih Tema yang Akan dimainkan Upaya pendidik dalam menciptakan suatu lingkungan yang memungkinkan terjadinya proses pembelajaran merupakan suatu keharusan, sebelum melaksanakan kegiatan pembelajaran di TK Pratama Kids Sukabumi Bandar Lampung terlebih dahulu menetapkan tema kegiatan yang hendak dicapai dalam bentuk penyusunan rencana pelaksananaan pembelajaran harian (RPPH) untuk menentukan pembelajaran dan kegiatan apa yang hendak dilaksanakan yang disesuaikan dengan kurikulum yang ada agar pembelajaran lebih terarah dan mengoptimalkan perkembangan anak. Mereka membuat RPPH tentang bermain peran yang telah disesuaikan dengan kurikulum. Dari hasil observasi yang peneliti lakukan dari tanggal 11 April sampai 11 Mei 2019 bahwasanya sebelum dimulainya pembelajaran guru sudah terlebih dahulu menyiapkan rencana pelaksanaan pembelajaran harian (RPPH) agar dapat tercapainya tujuan pembelajaran, di TK Pratama Kids Sukabumi Bandar Lampung guru dalam memilih tema telah menyiapkannya dalam sebauah Rencana Pelaksaan Pembelajaran (RPPH) terlebih dahulu, sehingga sebelum pembelajaran diterapkan maka guru telah menetapkan atau pun memilih tema untuk pembelajaran yang akan diterapkan dengan tema dan menggunakan metode bermain peran

2. Guru Membuat Naskah Skenario atau Jalan Cerita Untuk Bermain Peran 
Setelah guru menetapkan tema yang dipilih untuk bermain peran, guru menyiapkan naskah atau skenario yang akan dimainkan oleh anak. Guru menjelaskan terlebih dahulu tentang apa yang akan dimainkan dan mengarahkan anak sesuai dengan skenario atau pun naskah yang telah ditetapkan atau dibuat sesuai dengan tema yang telah ditentukan. Di TK Pratama Kids biasanya guru menjelaskan skenario atau pun mengarahkan tentang apa yang akan dimainkan oleh anak.Dari hasil penelitian bahwanya dalam membuat jalan cerita guru bukan terpaku pada naskah atau sknario namun lebih menjelaskan konsep yang akan dimainkan. Jadi guru membuat atau pun menjelaskan jalan cerita bersamaan anak saat bermain peran. Jadi anak-anak diberi arahan oleh guru untuk seperti apa dan anak mengembangkannya sendiri. Misalnya guru menjelaskan kepada Emir tukang sayur berjualan lalu emir berkata sayur sayur dan sebagainya. Guru menjelaskan terlebih dahulu tentang apa yang akan dimainkan dan mengarahkan anak sesuai dengan jalan cerita yang telah ditetapkan atau dibuat sesuai dengan tema yang telah ditentukan. Di TK Pratama Kids guru memang tidak membuat skenario atau naskah secara tertulis tetapi guru membuat jalan cerita yang akan dimainkan dan anak mengembangkan sesuai dengan imajinasinya. Jalan cerita tersebut disampaikan guru saat sebelum permainan atau saat guru bersamaan dengan permainan dilaksanakan.

3. Guru menyediakan alat-alat seperti alat atau media Sebelum dimulainya pembelajaran guru terlebih dahulu menyiapkan peralatan atau media yang akan digunakan dalam pembelajaran sesuai dengan tema yang telah ditetapkan. Contohnya ketika akan bermain peran tentang profesi dokter maka guru menyediakan dan menjelsakan alat-alat dokter seperti obat merah,suntikan dan lainlain. Saat Saat bermain peran pedagang sayuran guru menjelaskan tentang pasar, macam-macam sayur, dan bagaimana cara berdagang, saat menjadi polisi lalu lintas guru menjelaskan macam-macam tanda lampu merah dan profesi polisi, lalu saat menjadi guru, guru menjelaskan alat-alat yang digunakan guru saat mengajar, seperti spidol dan lain sebagainya. TK Pratama Kids Sukabumi Bandar Lampung telah menyediakan alat-alat yang akan digunakan untuk bermain. Berdasarkan observasi pada hari sebelum bermain peran guru telah memberi tahu kepada anak tentang besok akan melakukan bermain peran. Karena agar lebih menjiwai seperti peran yang dimainkan anak-anak yang dipilih guru di pinta untuk membawa konstum yang telah ditententukan dan guru atau pun sekolah yang menyediakan alat-alat seperti misalnya pada tema pedang sayur guru menyediakan sayuran, pada 
tema dokter sekolah menyediakan alat-alat dokter seperti suntikan obat dan sebagainya

Dari hasil penelitian yang peneliti laksanakan bahwasanya di TK Pratama Kids sudah mempunyai alat-alat untuk bermian peran hanya saja memaang belum begitu memadai, seperti pakaian. Oleh karenanya saat bermain peran guru terlebih dahulu memberi tahu kepada muridnya dan bekerjasama untuk membawa pakaian. Kemudian untuk bahan yang digunakan biasanya guru yang menyediakannya. Dalam hal ini guru harus bekerjasama dan berkomunikasi dengan orangtua murid.

\section{Guru Menjelaskan Teknis Permainan Bermain Peran}

Sebelum melakukan kegiatan bermain peran, guru menjelaskan terlebih dahulu tentang tema yang akan mereka mainkan, apa yang mereka lakukan dan apa tujuannya. Sebelum anak melakukan kegiatan bermain maka anak guru sebaiknya menjelaskan teknik atau pun aturan dan penjelasan dalam melakukan bermain, agar anak tidak bingung dan mengerti tentang tujuan bermain peran. Dari hasil penelitian yang peneliti laksanakan bahwasannya guru menjelaskan apa yang akan mereka lakukan dan bagaimana aturannya adalah saat awal pembelajaran. guru memberi tahu kepada anak bahwa mereka akan bermain peran. Lalu guru menjelaskan tentang tema misalnya: pada saat tema dokter; guru menjelaskan tentang dokter itu mengobati orang yang sakit, dokter ada yang laki-laki dan ada yang perempuan. Saat polisi lalu lintas guru menjelaskan tentang arti tanda-tanda rambu lalu lintas, merah berhenti, kuning hati-hati dan sebagainya. Lalu pada saat bermain peran tema dagang guru menjelaskan tentang berdagang, seperti dimana saja biasanya pedagang berjualan dan sebagainya. Hal ini dijelaskan agar anak dapat melihat dan mengetahui tentang keadaan sekitar dan mencoba memainkan peran yang sama.

5. Guru Memilih Peran Anak yang Akan Bermain Peran

Dalam bermain peran ada anak-anak yang bermain peran dan ada yang belum mendapat giliran yang ditetapkan sebagai pendengar, anak-anak mendengarkan dan melihat temannya bermain peran dan menunggu gilirannya untuk bermain peran.

Berdasarkan penelitian yang peneliti lakukan guru memilih anak yang melakukan pemeran untuk pertama kali, karena jumlah anak-anak dalam pemeran disesuaikan dengan tema dan banyaknya pemeran, maka ada anak-anak yang belum mendapatkan giliran bermain. Guru memilih anak yang akan bermain pada saat awal bermain. setelah selesai pemeranan pertama guru mengajukan kepada anak untuk siapa yang ingin bermain peran dan memainkan peran apa yang mereka sukai. Hal ini juga dapat melatih anak menghargai temannya yang tampil, bekerjasama dan sabar dalam menunggu gilirannya dalam bermain

6. Menceritakan Sambil Mengatur Adegan Pertama 
Dalam bermain peran agar anak lebih memahami tentang apa yang akan diperankan sebagaiknya guru menjelaskan dan menceritakan apa yang akan diperankan oleh anak. Dari hasil penelitian di TK Pratama Kids Sukabumi bahwasannya guru biasanya sambil menceritakan alur yakni bersamaan dengan saat pemeran mulai dimainkan. Jadi guru sambil bercerita alur cerita bersmaan dengan anak memainkan peran yang diperankannya. Seperti guru bercerita bahwasnya ada pedagang sayur yang lewat dan berkata yur..sayur lalu anak yang memainkan peran sebagai pedagang memainkan perannya dengan berkata yur..sayur. dan lain sebagainya.

7. Guru Mendiskusikan Tentang Nilai-Nilai Yang Terkandung Dari Kegiatan Bermain Peran

Dalam bermain peran agar anak lebih mengerti nilai-nilai yang terkandung dalam materi kegiatan bermain, guru mendiskusikan atau pun mengulas kembali tentang kegiatan bermain peran dengan melakukan tanya jawab, seperti misalnya jika ada teman atau saudara yang sakit sebaiknya dijenguk, atau kita harus mematuhi peraturan lalu lintas, jika lampu merah harus berhenti, tidak ribut saat upacara dan sebagainya.

di TK Pratama Kids biasanya guru mengulas kembali dengan melakukan tanya jawab kepada anak tentang senang atau tidak bermain peran dan apasaja nilai yang terkandung dalam bermain peran. Jika telah menjelaskan di depan berdasarkan hasil pengamatan mereka hanya menanyakan bagaimana perasaan anak seperti pada saat bermain peran tema dokter. Dan guru juga menjelaskan dan mengulas kembali peran dan nilai-nilai yang terkandung dalamnya pembelajaran.

8. Guru Mengevaluasi Kerja Atau Pun Hasil Dari Bermain Peran

Untuk mengetahui tentang perkembangan anak, guru melakukan evaluasi hasil dari kegiatan bermain peran, di TK Pratama Kids Sukabumi Bandar Lampung mengevaluasi hasil belajar dengan menggunakan diantaranya ceklis, anekdot sebagai alat untuk mengetahui perkembangan anak.

Berdasarkan hasil analisis dan pengamatan peneliti untuk mengembangkan kecerdasan intrapersonal anak guru lebih merangsang dalam mengembangkannya dalam diri anak dengan langkah menjelaskan kepada anak dan meminta mereka untuk mengamati dilingkungannya. Kemudian kecerdasan interpesonalnya dikembangkan dan dirangsang ketika anak mulai memainkan peran dan bagaimana cara anak bekerjasama dengan orang lain atau temannya. Dalam penyediaan bahan dan alat untuk menunjang bermain peran guru bekerjasama dengan orangtua hal ini dilihat dari guru yang memberi tahu siswa untuk membawa bahan seperti sayuran pada harri sebelum dilaksanakannya bermain peran. 
Setelah diterapkan bermain peran dengan langkah tersebut sesuai dengan indikator kecerdasan interpersonal dan intrapersonal anak didapatkan hasil sebagai berikut:

Tabel 1.

Penilaian Perkembangan Kecerdasan Interpersonal Anak Di Tk Pratama Kids Sukabumi Bandar Lampung Tahun ajaran 2018/2019

\begin{tabular}{|l|l|}
\hline Interpersonal & Frek \\
\hline $\mathrm{BB}$ & 0 \\
\hline $\mathrm{MB}$ & 4 \\
\hline $\mathrm{BSH}$ & 13 \\
\hline $\mathrm{BSB}$ & 5 \\
\hline
\end{tabular}

Berdasarkan hasil penelitian dalam tabel diatas tentang kecerdasan interpersonal anak terdapat 0 anak yang BB (belum berkembang), 4 anak yang MB (mulai berkembang), 13 anak yang BSH (berkembang sesuai harapan), dan 5 anak yang BSB (berkembang sangat baik)

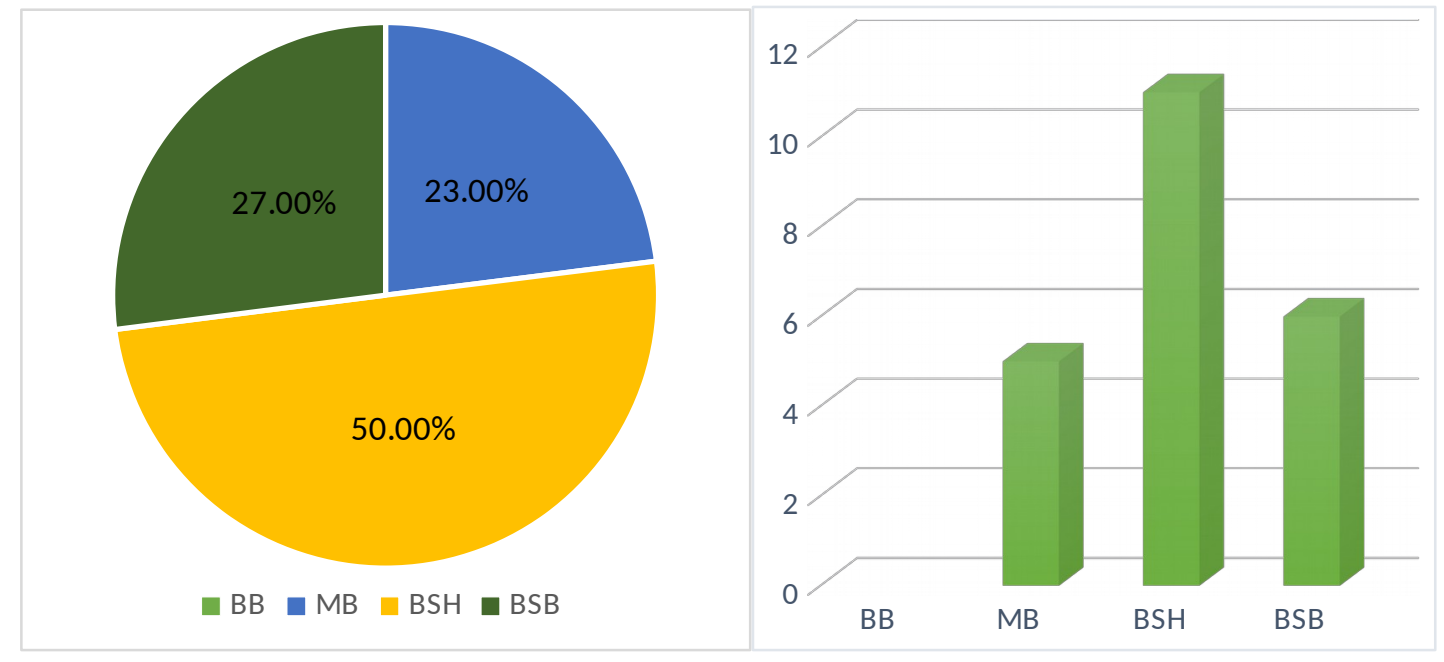

Gambar 1. Grafik Persentase Data Perkembangan Kecerdasan Interpersonal Anak

Jumlah anak sebanyak 22 anak,tidak ada anak yang belum berkembang, 18\% anak mulai berkembang, 54\% anak berkembang sangat baik, 23\% anak berkembang sesuai harapan. Dengan demikian dapat dikatakan bahwasannya perkembangan kecerdasan interpersonal anak di TK Pratama Kids Sukabumi sudah berkembang dengan baik.

Dengan Indikator penilaian kecerdasan interpersonal sebagai berikut:

1. Anak mampu bekerjasama dengan temannya seperti ketika bermain peran

2. Anak peduli kepada temannya sepeti saling tolong menolong dengan temannya

3. Anak mau berbagi makanan atau alat bermain peran dengan temannya

4. Anak berani tampil di depan kelas memainkan peran.

5. Anak mampu menghargai temannya yang tampil bermain peran 
Tabel 2.

Penilaian Perkembangan Kecerdasan Interpersonal Anak

Di Tk Pratama Kids Sukabumi Bandar Lampung Tahun ajaran 2018/2019

\begin{tabular}{|l|l|}
\hline Intrapersonal & Frek \\
\hline $\mathrm{BB}$ & 0 \\
\hline $\mathrm{MB}$ & 5 \\
\hline $\mathrm{BSH}$ & 11 \\
\hline $\mathrm{BSB}$ & 6 \\
\hline
\end{tabular}

Berdasarkan hasil penelitian dalam tabel diatas tentang kecerdasan intrapersonal anak bahwa terdapat 0 anak yang $\mathrm{BB}$ (belum berkembang), 5 anak yang MB (mulai berkembang), 11 anak yang BSH (berkembang sesuai harapan), dan 6 anak yang BSB (berkembang sangat baik)

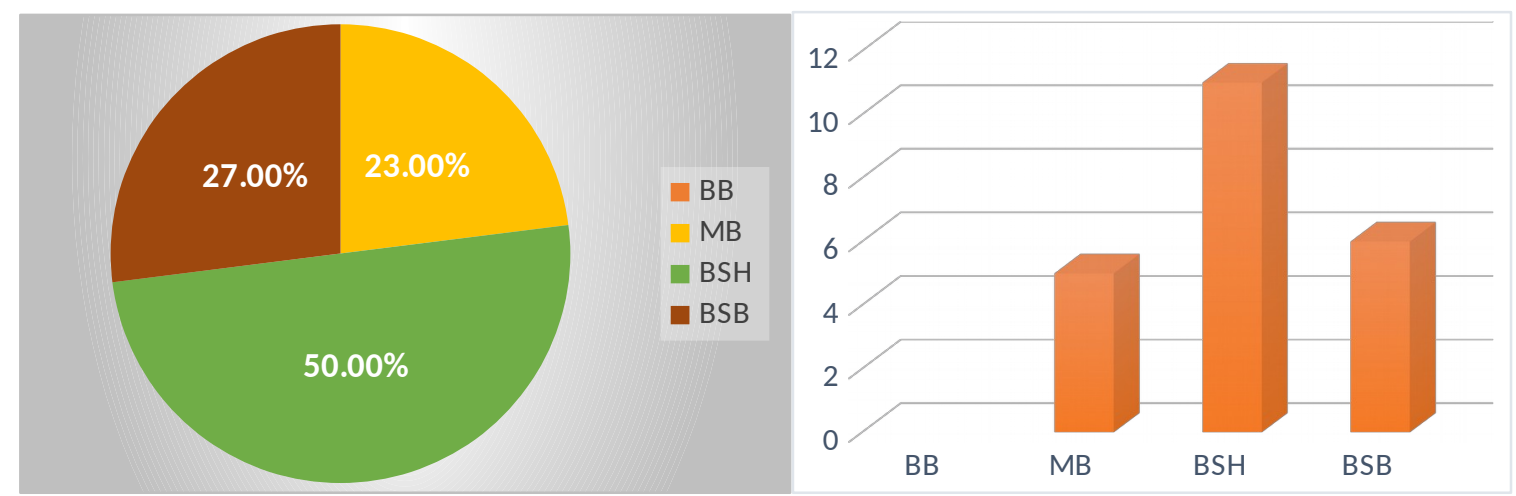

Gambar 2. Grafik hasil Perkembangan Kecerdasan Intrapersonal Anak

Jumlah anak sebanyak 22 anak,tidak ada anak yang belum berkembang, 23\% anak mulai berkembang, 50\% anak berkembang sangat baik, 27\% anak berkembang sesuai harapan. Dengan demikian dapat dikatakan bahwasannya perkembangan kecerdasan interpersonal anak di TK Pratama Kids Sukabumi sudah berkembang dengan baik. Indikator penilaian perkembangan kecerdasan intrapersonal ini adalah

1. Anak percaya diri ketika memainkan perannya

2. Anak semangat ketika bermain peran bersama temannya

3. Anak sabar dalam menunggu giliran bermain

4. Anak mampu mengerjakan sendiri tugas dengan baik ketika ditinggal sendiri

5. Anak mampu mengeksperesikan perasaannya seperti tertawa ketika bahagia sesuai dengan peran yang dimainkan

Keterangan Penilaian:

BB : Belum Berkembang, apabila anak melakukannya harus dengan bimbingan atau dicontohkan oleh guru 
MB : Mulai Berkembang, apabila anak melakukannya masih harus diingatkan dan dibantu oleh guru

BSH : Berkembang Sesuai Harapan, apabila anak sudah mampu melakukannya secara mandiri dan konsisten tanpa harus diingatkan atau dicontohkan oleh guru.

BSB : Berkembang Sangat Baik, apabila anak sudah melakukannya secara mandiri dan sudah mampu membantu temannya yang belum mencapai kemampuan sesuai dengan indikator yang diharapkan. ${ }^{23}$

\section{SIMPULAN DAN SARAN}

Berdasarkan hasil penelitian yang telah dilakukan oleh peneliti bahwa penerapan metode bermain peran (Role Playing) dapat mengembangkan kecerdasan interpersonal dan intrapersonal anak. Hal tersebut dilakukan oleh pendidik dengan langkah-langkah yang telah diterapkan diatas dimulai dari menetapkan tema pembelajaran hingga mengevaluasi pembelajaran. Dengan bermain peran anak bisa dilatih salah satunya bekerjasama dan mengendalikan dirinya. Hal ini juga dapat dilihat kecerdasan interpersonal anak dalam kategori belum berkembang 0 anak $(0 \%)$, mulai berkembang ada anak kecerdasan intrapersonal ada 4 anak (18\%), anak yang berkembang sesuai harapan ada 13 anak (59\%), anak yang berkembang sangat baik ada 5 anak (23\% anak yang berkembang sangat baik. Kemudian untuk kecerdasan intrapersonalnya ada 0 anak (0\%) anak belum berkembang, 5 anak (23\%) yang mulai berkembang, ada 11 anak (50\%) anak yang berkembang sesuai harapan dan ada 6 anak (27\%) anak yang berkembang sangat baik.

Dalam penelitian ini penulis mengucapkan terimakasih banyak kepada semua pihak yang telah berkontribusi sehingga terlaksannya dan di dapatkan hasil penelitian ini. Mengingat pentingnya kecerdasan untuk anak maka sebaiknya pendidik dan semua pihak terus mengembangkan metode-motode agar perkembangan anak berjalan dengan optimal.

DAFTAR PUSTAKAXAndrianus Krobo. (2014).Peningkatan Kecerdasan Intrapersonal melalui Kegiatan Bermain Peran. Jurnal Pendidikan Anak Usia Dini, 8.1 (2014), 2534

Deni Damayanti. (2018). Senang Dan Bahagia Menjadi Guru PAUD.Yogyakarta: Araska

Desti Pujiati. (2013). Peningkatan Keterampilan Sosial Melalui Bermain Peran. Jurnal Pendidikan Anak Usia Dini. Volume 7 Edisi 2, November 2013

23 Kompleks Perkantoran Kemdikbud, 'Direktorat Pembinaan Pendidikan Anak Usia Dini', 021, 2008, $1-34$. 
Jumanta, Handayana. (2017) Model Dan Metode Pembelajaran Kreatif Dan Berkarakter.Bogor: Ghalia Indonesia

Kemdikbud, Kompleks Perkantoran, 'Direktorat Pembinaan Pendidikan Anak Usia Dini', $021,2008,1-34$

Muhammad Yaumi dan Nurdin Ibrahim. (2016) Pembelajaran Berbasis Kecerdasan Jamak(Multiple Intelegensi).Jakarta: Prenadamedia Group

Mukhtar Latif. (2013). Pendidikan Anak Usia Dini. Jakarta: Prenadamedia Group

Muhammad Yusri Bahtiar. (2017) Pengaruh Bermain Peran Terhadap Interpersonal Pada Anak Kelas A Di Tk Buah Hati Kota Makassar Jurnal Pendidikan Anak, Vol. 3 No 2 September 2017

Mulyasa. (2016). Manajemen PAUD. Bandung: PT Rosdakarya

Panji Hermoyo. (2014). Membentuk Komunikasi Yang Efektif Pada Masa Perkembangan. Membentuk Komunikasi Efektif.

Suarca, Kadek, Soetjiningsih Soetjiningsih, and IGA. Endah Ardjana. (2016) 'Kecerdasan Majemuk Pada Anak', Sari Pediatri, $2016<$ https://doi.org/10.14238/sp7.2.2005.8592>

Suyadi.(2014). Teori Pembelajaran Anak Usia Dini. Bandung: PT Rosdakarya

T. Musfiroh. (2014). Pengembangan Kecerdasan Majemuk. Hakikat Kecerdasan Majemuk $\begin{array}{llll}\text { (Multiple } & \text { Intelegences), } & 60 & \text { (2014), }\end{array}$ $<$ http://repository.ut.ac.id/4713/2/PAUD4404-TM.pdf>

Undang-Undang.(2016).Sistem Pendidikan Nasional.Yogyakarta: Pustaka Belajar 